\title{
AN AUTOPSY CASE OF ATYPICAL WEGENER'S DISEASE WITH RECURRENT CONSTRICTIVE TRACHEOBRONCHITIS
}

\author{
By \\ KIICHI SATO \\ From Department of Pathology, Institute for the Deaf, Tokyo Medical \\ and Dental University. (Prof. Masatoyo Akiyoshi)
}

\begin{abstract}
A 39-year-old housewife had lobectomy of the right upper lung lobe because of pulmonary tuberculosis 8 years ago. After that the patient was suffering from chronic productive trachitis. Although its clinical diagnosis was not established, various treatments were done, resulting in remis. sion of the trachitis for about 5 years. However, proliferation of atypical granuloma into tracheal lumen gradually became increased and led to dea-
\end{abstract}

th. Autopsy revealed that main pathologic change consisted of cicatrical constrictive chronic trachitis and granulomatous angitis similar to Wegener's granulomatosis of the bronchi. The tracheal lesion was thought to have been caused by the granulomatous angitis. Basing on the findings, the present case was considered as Wegener's disease with atypical pathologic manifestation in the lower respiratory tract.

\section{再発性狭窄性気管気管支炎を起した 異型Wegener 氏病（剖検例）}

\author{
東京医科菌科大学難㯖研究施設病理部（主任：秋吉正豊教授）
}

佐藤喜

\footnotetext{
緒言

本剖検例灶肺結核で右上葉切除術をらけた既往をるつ 39 才家婦で死亡迄，10 数年間にわたつて臨床的に慢性 增殖性気管炎として本態不明のまをに多彩な治療をう け，この間；約 5 年間小康を得たにるかかからず気管内 腔の異常肉莪增殖のために死亡した例であり，剖㭘によ

り Wegener 氏病と診断した例である。

本剖検例の特改は上気道の病変で法鞍鼻之鼠中隔穿孔 だけであり，主なる病変は気管内腔の病变である．即ち 臨床的には反復す万海痕性狭窄性慢性気管気管支炎の像 を呈しており，病理組織学的には Wegener 氏病の肉 芽腫性血管焱が治癒した像と考党たすので，この観点か ら，この例をWegener 氏病の異型像 とした例である。 剖検例（東医雪大 SN 2684) 39 才家婦 昭和 38 年 11 月 6 日死亡

臨 床 歴

昭和 25 年頃，鼻が 次第に鞍鼻になることに家人は気 ついていたが特別に診療をらけなかつた。

26 年 6 月榎濑と喀痰揢出がはげしく某病院内科を受 診し，レントゲン検查にて右肺結核と診断され入院，化 学療法 (SM 毎日 $1 \mathrm{~g}+$ PAS $8 \mathrm{~g}$ ) と治療的気胸を行つ た。

同年10月化学療法を中止し退院．自宅化て療堡して いたが気胸は 27 年 5 月迄継続した。

以後键診のみで 3 年半経過したが昭和 30 年 3 月再び 咳嗽，喀痰が現われたので本学国府台分院を訪れ SM 週 $2 \mathrm{~g}+\mathrm{PAS}$ 連日 $8 \mathrm{~g}$ の化学療法を4ヶ月行つた。 そ 乙て同年 8 月入院 乙, INH 週 2 回法 $+\mathrm{SM}$ 週 $2 \mathrm{~g}+$ PAS 1 日 8g を4ケ月続けた。 そして右上葉 $\mathrm{S}_{2}$ の空 洞が跋縮してきたので 11 月に右上葉切除術と N. phrenicus の正挫を行つた，病巣は $S_{1} S_{2}$ に限局し中下葉 飞病的变化を認めなかつた。術後経過む良く化学療法を 
続けていたが，31 年 4 月治瘾退院した。退院時には発 声，呼吸の障害は認められなからたが 3 月後の 7 月頃 から榎声に気づき9月には呼吸困難が始まり次第に雨症 状が增覀してきた，当初，肺手術時の声帯の神経性麻㾇 と肺活量の減少のために起つた庭状と考えていた。しか し漸次呼吸困難が強くなり同年 11 月にチアノ一ゼのた め某病院炕救急入院し直ちに気管切開術をらけた。この 時声門下院上上部気管腔内が肉等で埋められていること が解った。この肉芽の病理組織学検查では非特異性の炎 症であつたとのことである、しかし呼吸困難が続くので 翌 32 年 1 月に第 1 回の搌:頭截開術をうけたが術後間も なく肉芽の增殖があり，カニューレ装用のまま本学分院 外科炕転送さ机た。分院では 5 月下旬に第 2 回の截開術 在行ない氛管腔内者充した肉芽組織を得離除去した，1 週閂後には声門が小指插入可能となり一時喉頭呼吸可能 となつたが，漸次術前の状態になり，そのまま本学耳睤

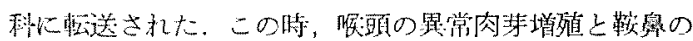

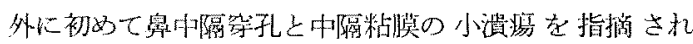
た.この謴瘍は既往歴と SM の投与に刘果があつたの で臨床的には結核性潰㩧之考克ていた。しかし一般状態 の衰彁が強からたために体力の回復をまち 33 年 3 月下 旬经頭形成術の前手段として第 3 回目の㩔頭截開術を 行つた，この時内腔は輍骨様の肉芽が增殖し管腔は僅か $1 \mathrm{~mm}$ であつた。この肉将を元の管腔の広さ迄除去し 創面全体に植皮を行つたが不成功に 終つたので2週間 後に Acrylて作つた Obturator を插入した。 しかし約 1 ケ月半で Obturator は気管前面に押 し出されその後 4日目には再び気管腔は，肉芽で塞がつてしまつた。

そこで術創が咯開しても気管壁の压定を維持すること を目的として Tantalum の薄板で気管内壁に密皓させ る太さで長さ $3 \mathrm{~cm}$ の Tube を試作し 33 年 8 月第 4 回 目の喉頭截開術を行い肉莱搔爬後これを銀線で固定し た. その後 4 ケ月目にこれを除去した所輪状軟骨部気管

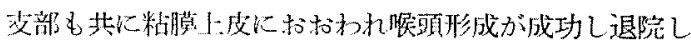
た ${ }^{14)}$.

\section{その侵約与排は呵吸困難もなく経過した。}

今回は 38 年 9 月に入ると再び軽度の呼吸困難と唋嗽 があり次第に增覀してきたので 10 月31 日に再び本学耳 奥科汇入院した，入院時の呼吸困難法軽度であり，呼吸 数は16である。

前頸部孔長さ $3 \mathrm{~cm}$, 巾 $1 \mathrm{~cm}$ の脘頭擮開孔がある。こ の下緑上り約 $5 \mathrm{~cm}$ の所に前後上り弁状に隆起した肉芽 の增殖があり気管腔は狭く前後 $5 \mathrm{~mm}$, 左右径は $8 \mathrm{~mm}$
で吸気時には更に狭くなる傾向があつた，11月4日モ リヨドールをスプレーで吸入させ，レントダン撮影を行 つた所，気管分岐部直上に狭窄を認めた．従つて的废生 気管狭窄症の診断で外科的治療を考慮中に 翌 5 日午前 4 時頃より呼吸困難が甚だしくチアノーゼが現われたので 插管加圧人工呼吸を行つたが脈膊次第に微弱となり血压 下降乙，開胸後心缄マッサージを行つて好転せず，そ れから30 分後に死亡した。

今回の臨床検查は病状悪化のため詳しく調べることが できす Hb 65\% Rote $290 \times 10^{4}$ Weiß 6500 で頜血が あり，喀咨の結核菌は陰性でワッセルマン反応陰性、简 部レントゲンでは雨肺野に境界明療なクルミの陰影を数

別 図
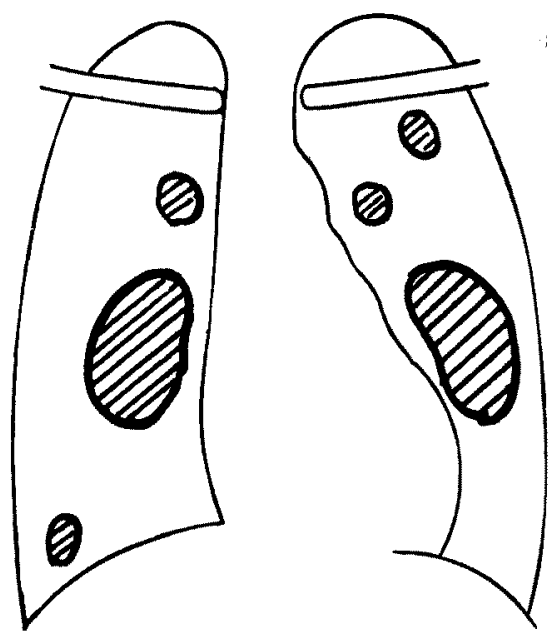

個認めたので臨床的には肺腫㻛む考劣ていた（则図）

なお今回の治療はクロマイ1日 $1 \mathrm{~g}$ 筋注のみであっ た.

\section{剖検所見}

著しく、るいそうした忤女性屋である。(休重 $27 \mathrm{~kg}$

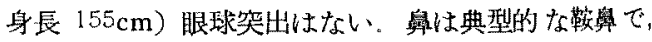
鼻中隔案孔があるが溃瑒はない（写真 1)

㩔頭部：著明な声門水腫があり声带の高さで粘膜絹 織の肥厚があり狭鏃を起こし内腔は径 $0.7 \mathrm{~cm}$ ，ての下に 岍頍截開孔がありその真下はやや円筒状の摭張を示し $1.5 \mathrm{~cm}$ 《拨がり再び分岐部で狭窄し左 0.4 右 $0.7 \mathrm{~cm} て ゙$ ある。な和截開孔下の粘膜に $1 \times 2 \mathrm{~cm}$ の潰瘍がある。 (写真 2) 
写真 1

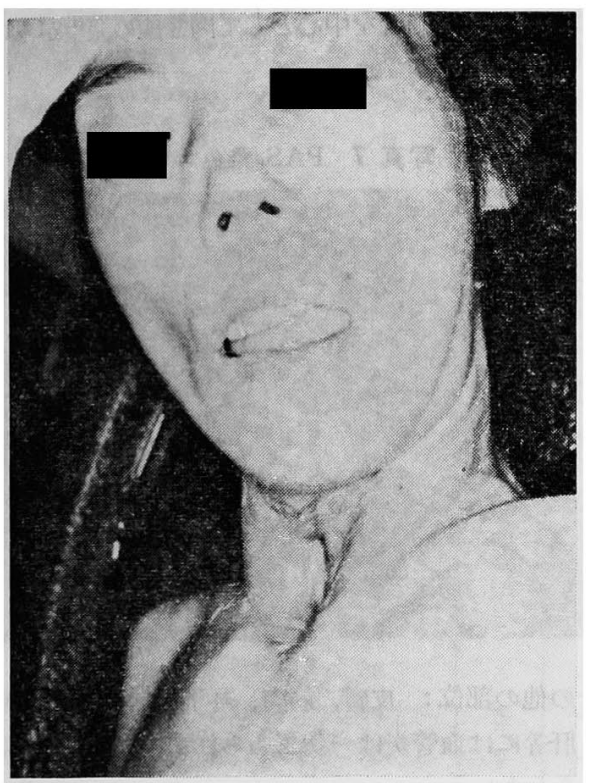

写真 2

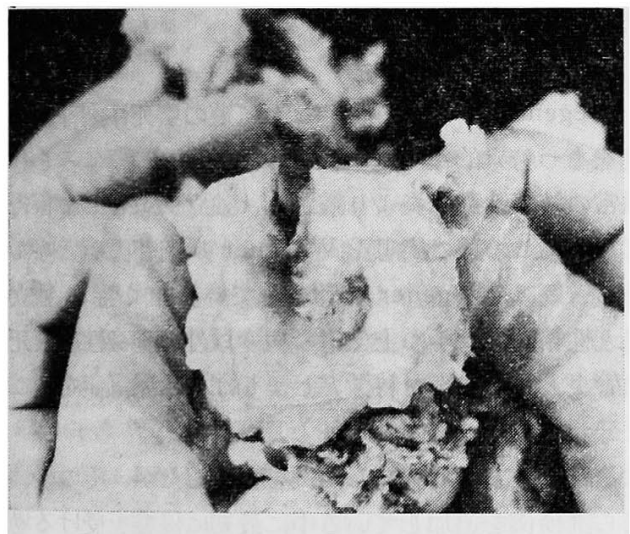

肺 (左 $380 \mathrm{~g}$, 右 $250 \mathrm{~g}$ ):

雨肺にはクルミ大の特有な硫黄色を呈する硬い結節数 ケが散在し，又第 1 第 2 次気管支粘膛に肥厚があり内膑 が者しく狭袏している. 右上葉切除をらけた材料につい ては今回は病理組織学的檢索を行うことができなかつ た. (写真 3 )

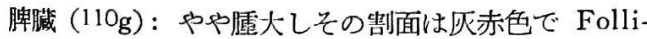
kel は米粒大で, その存在は明瞭であるが境界不解明で ある.

腎葴 (左 $160 \mathrm{~g}$, 右 $170 \mathrm{~g}$ )：やや腫大乙表面は皮膜下 の小出血点の多発がみられる.
写真 3

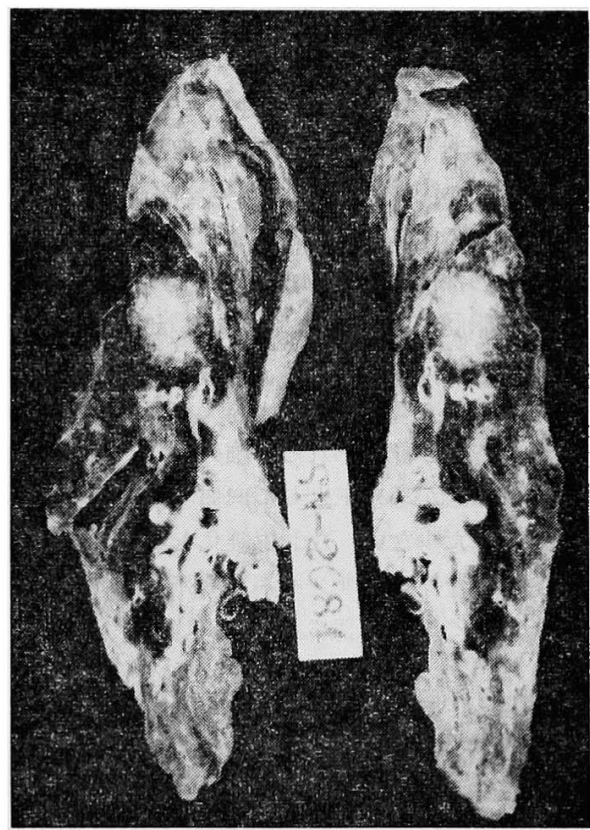

心臓 $(230 \mathrm{~g})$ 肝臓 $(1100 \mathrm{~g})$ には肉眼的に著しい変化 はない。

リンパ腺腄脹は, 肺門リンパ腺が数ヶみられるがその 他のリンパ腺の鬾脹はみられない。

\section{組織学的所見}

喉頭部：声带部粘脱肥厚の表面は移植皮膚再生延長 による表皮により置換されている. 気管分岐部の近くで は，粘膜の肥厚が更に著しくなり $0.5 〜 0.8 \mathrm{~cm}$ に及んで いる，この部分では線維化が強く物こり潰痬形成があ る.なお，肥厚部の軟骨に接している部位には多数の気

写真 4 ワンギーソン染色 $\times 5$

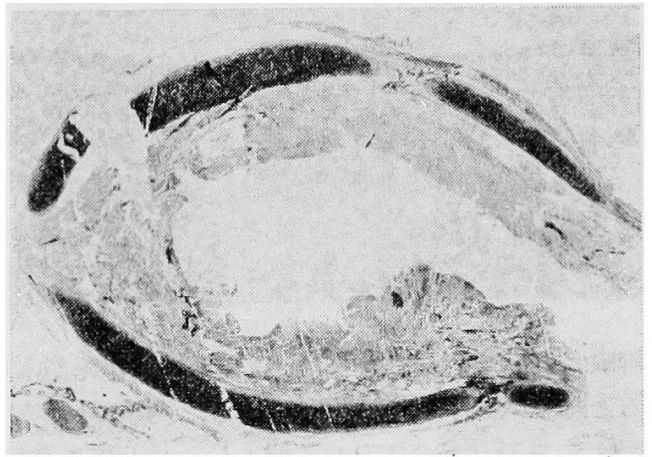


管支腺の囊状の拡張がある．線維性の粘膜肥厚部には多 数のリンパ球, 形質細胞浸潤があるが, 血管炎㧊よび肉 芽腫は全く認められない（写真 4)

肺：硬い病巣部は著しい線維化を示し，それらの中 心部は壌死におらいり，ランゲルハンス型ないし異物巨 細胞を伴なつた肉芽腫の形成もみられる.この肉芽腫を 形成する細胞の中には，かなり多数の大食細胞が現われ ている.この部位に Sudan 四染色をほと゚こすと, これ らは多量の脂肪を摂取していることがわかる.チール， ネルセン染色では壤死部には，抗酸菌は認められない。 なおこれらの肉芽腫の中には中等大血管より細小動静脈 に壤死性血管炎が認められる，翌死を起した血管壁には 多数の細胞浔潤があり主として白血球，プラズマ球で好 酸球ははなはだ少ない。な㟫維化をまぬかれた部位に 扣いても小さなフイブリノイド，壌死性血管炎および， それをとりまく細胞浸潤がある。(写真 5)

写真 $5 \mathrm{H} \cdot \mathrm{E}$ 染色 $\times 180$

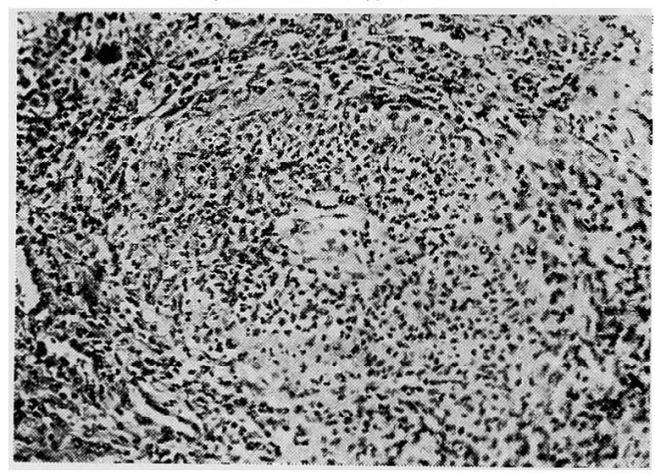

写真 6 H.E 染色 $\times 180$

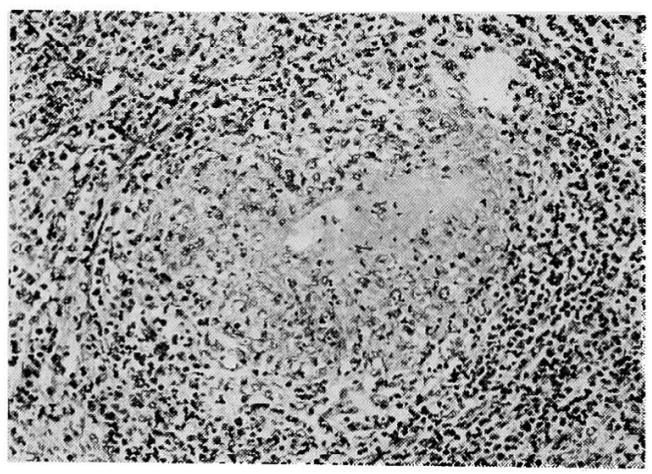

脾蔵： 主として濾胞動脈に強い壤死性血管炎がみら れると同時に細胞の增殖が認められる. (写真 6)

腎蔵：糸球体が全体として腫大し，いわゆる内皮細
胞が増殖し急性糸球体腎炎の組織像を呈している,なお 稀に腎皮質の尿細管を中心として肉芽腫の発生がみられ る. (写真 7)

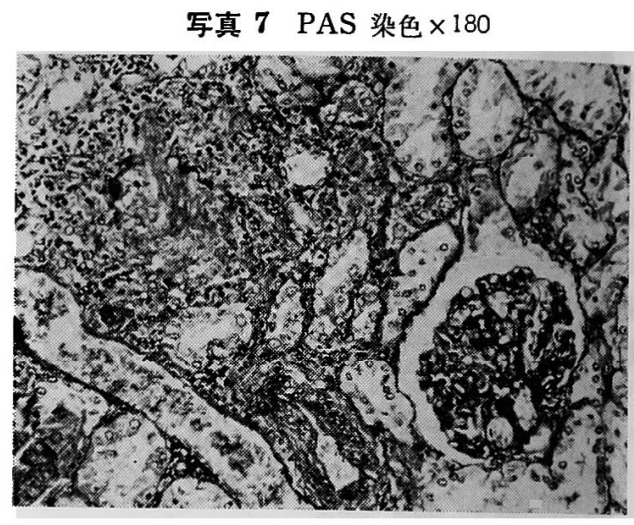

その他の部位：皮慮, 筋肉, 耳下腺, 顎下腺, 舌下 腺，肝等には血管炎は一切認められず特記すべき所見は 認められない.

肺門リンパ腺は宸素沈着を認めるが，腫瘍性変化を認 めない。

\section{考按}

Wegener 1)2) が 1936 年に上気道の壤死性肉芽腫性病 変をるつ特異的な 3 剖検例を報告し, 諸臓器にみられる 通常の結節性動脈炎より鑑別し, 独立疾患として報告し て以来, この種の疾患をWegener 氏肉芽腫症と呼んで いる。既に Wegener が報告している如く特に独立疾 患と性格づけた中に上気道の病变以外に全身性の裹死性 血管炎と糸球体炎を特徵とし，しばしば尿毒症を括こす と云われ，その後 Godman 3) 及びFahey 4) らが 1954 年 にそれ迄の剖検で確認した例を整理したが，その後，こ れら剖検例を追加している中に最初に侵熟を受ける場即

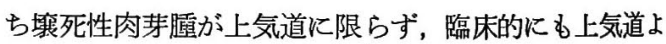
り，肺に多くみられる例が報告されるようになり 1959 年 Altmann ${ }^{5)}$ は，その剖検例 2例を報告し，主として 気道系に壌死性肉芽を認めたすのを Rhinogene Form とし, 主病変が肺にみられ気道系に変化のなかつたもの を Pulumonale Form と2大別した.

本剖検例は Altmann の述べた Pulmonale Form に類似するものと思われるが，それ以前に反復した上気 道の病変が自然ないしは治療により治癒し, 現在そこに 特記すべき雍死性肉芽腫及び血管炎は認められないが， 肺腎脾にそれぞれ特有な肉芽尰が認められた例でありそ 
の剖㭘所見からWegener 氏病と診断ず゚さと考光た。 な就本剖検例の特色を比較検討寸る目的から我国に䗆 ける垠告例を通覧してみると，剖検後原著となり報告さ

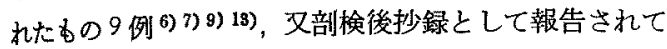

いるもの4 例 ${ }^{8}$ 10)11１2）ありとの他生存例と剖检輯報よ り選択して専現在迄㒖か３0数例に一゙ぎない，著者は剖 检後の報告例 13 例を参考にし本剖検例に特徽的たつた 上気道病変につき比較检湗を行つた（別表）

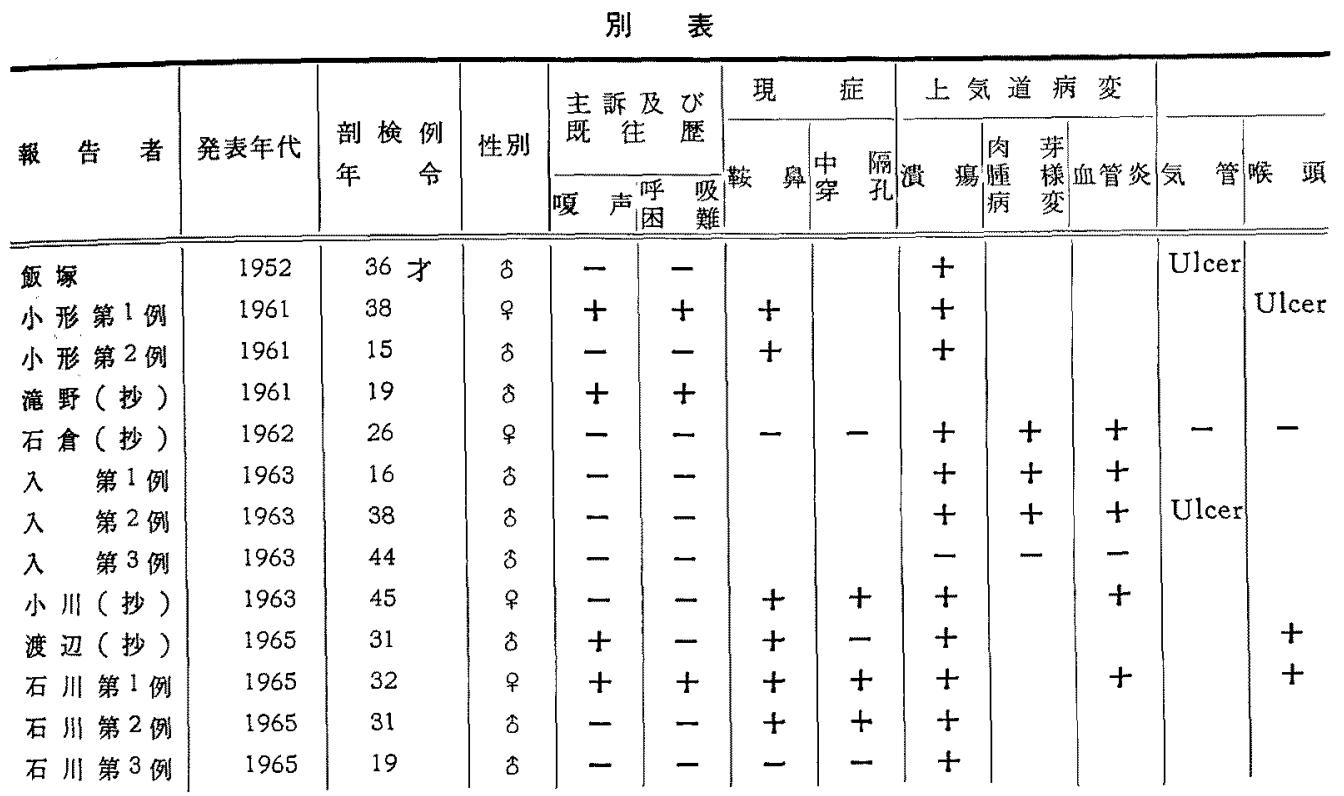

年令及び性別は表の如く10 代〜40代沈わたつてあり 男性火多小。

臨床憷では，一般にこの種の疾患の主訴及び既往歷に

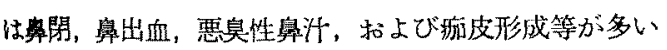
が，本例にみられる如く，愳声と呼吸困難を前駆症状と した例では榎声 4 例，呼吸困難 3 例にみられた。これは Walton の報告例炕比较すると高率である。

現定歴で本例の如く鞍奥と鼻中隔穿孔がみられるが 鞍鼻仕6 例の報告があり，鼻中隔穿孔の記截は3 例にみ られた。しかしの3例共に鼻腔内に溃湯形成がみられ るが本例の如く溃瘍形成なく穿孔のみを認めた例俚見当

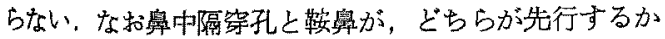
蜘告者によりまちまちで不定であるが渡辺例の如く鞍

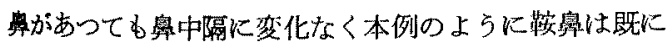
気らかれていたが中隔穿孔は本学を訪れた時に指摘され た事から，あるいは鞍鼻が先行すると推察できる。

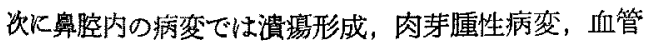
炎の存在を主としてみてみるとたた1例（入氏の第 3 例)に全然諰めない例の報告もある。本例は残念ながら 鼻腔内の剖検材料を得ることができなかつた，次に本例
のよらな倨頭気管内の異常肉芽增殖についての報告は倨 頭に肉著を認めたもの渡边氏例，石川の第 1 例の 2 例で あるが反復する增殖像はない，本例の如き気管内腔に肉 芽を認めたのは皆無であり３例に小潰瘍を認めた報告が ある。

しかしながら本例の加き腒䫒から気管にかけて公範囲

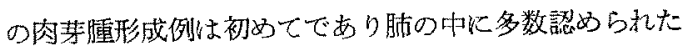

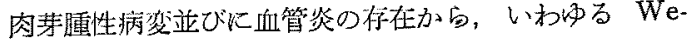
gener 氏病の Pulmonale From の買型像であると考 学。

\section{結 語}

郚床的に艮期に放たつて慢性增殖性気管炎と乙て本熊

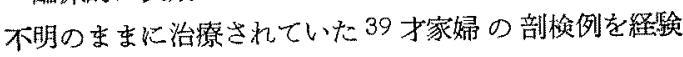

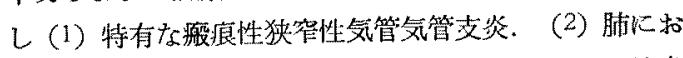

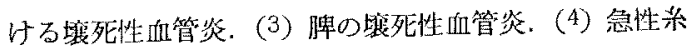
球体腎炎の所見から Wegener 氏狱亡䛦断した 1 例を 報告した。

\section{參考文献}

1) Wegener F.: Lber eine eigenartige rhinogene Granulomatose mit besonderer Beteiligung des Ar- 
teriensystems und der Nieren. Beitr. Path. Anat. 102: 36 38, $1939 . \quad$ 2) Wegener, F.: Über generalisierte, septische Gefäßerkrankungen. Vech. Dtsch. Path. Ges. 29: 202 209, 1937. 3) Godman, G.C. and Chung, J.: Wegener's Granulomatosis Pathology \& Review of the Literature. Arch. of Path. 58: 533, 1954. 4) Fahey, J. L. et al.: Wegener's granluomatosis. Am. J. Med. 17: 168, 1954. 5) Altman, H.: Ein Beitrag zur Histologie und zur Einordnung der Wegenerschen Granulomatose. Beitr. path. Anat. 121 (2) ä 211. 1959. 6) 飯塚楥他: 内歲の多発性肉芽腫と沉動脈炎を伴つた 肉芽腫性鼻炎, 日病会誌（地方），41：108～109：1952. 7) 小形岳三郎: Wegener 肉芽腫症の 2 剖検例. 日病 会誌, 50: 413〜1961８）滰野賢一他：嗄声を主 訴としたWegener 氏肉芽腫症の 1 例. 日耳䊩, 64: 345: 1961. 9) 入 他: Wegener's Granulomatosis の2 剖検例. 臨床病理, 11: 160: 1963. 10) 小川常二他：Wegener 氏病の一剖検例. 日耳鼻, 66: 1094, 1963. 11) 石倉武崔他：Wegener 氏肉
芽腫症について，日耳鼻，65；1382～1402，1962. 12) 渡辺網彦他: Wegener 氏肉芽腫症の1症例. 日 耳鼻, 68:806, 1965. 13) 石川哮: Wegener 氏 肉芽腫症及びその類似疾患の血清学的研究. 日耳鼻, 68：513〜 527，1965. 14）堀口申作他：タンタル ム，チユーブを用いた喉頭形成術，形成美容外科，2: 192 200，1959. 15）佐藤喜一：再発性狭窄性気管 気管支炎を起た異型 Wegener 氏病医学のあゆみ 52 : 168 170, 1965.

御指導と御校閲を賜つた本学病理学教室石井善一 郎教授並びに御鞭撻頂いた恩師秋吉正豊教授に厚く 感謝致します．又耳鼾科教室堀口教授，浜口助教授 鮠原助教授, 山下講師の御助言に謝意を表します. 又御協力下さつた雨宮講師はしめ病理学, 耳鼻科教 室員各位に感謝します。本論文の要旨は炤和 39 年 6 月第 46 回東京病理集談会に拈いて発表した.

（原稳到着 $=$ 昭和 41.5 .12 日）

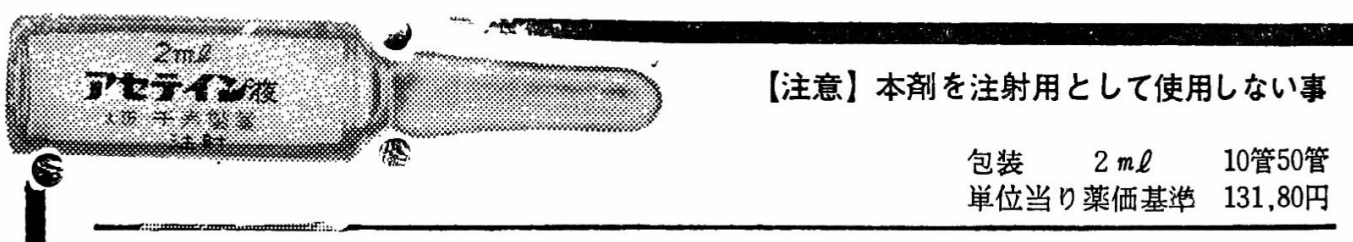

受道粘虂溶解成

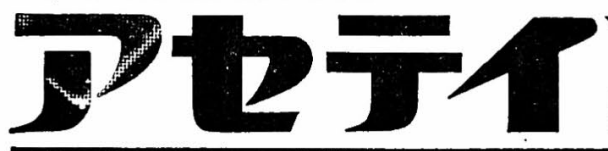

【通店证]

（1）全ての術後肺合併定の予防並びに治崉。（特に全音 拔管時を含む)。

（2）肺感染症（上気道炎、急性・慢性気管支资、侵性肺 気腫、肺化滕㱏) の治浓の際。

（3）匃管支造影法、気管支鏡検查、肺澡細胞影施行時に おける前処置及び後処置として。

(4) 気管支切開後の分泌物吸引時および末期患者の気管 支分泌物による呼吸困蜼の際、粘液の溶解を目的と して使用する。

【用法・用是】

通常 1 回 $1 \sim 4 m \ell$ 、単独または他の薬剤を混じて気管内 に直接注入またはネブライザーにより櫴第吸入する。 证状によっては改善をみるまで频回に使用する。

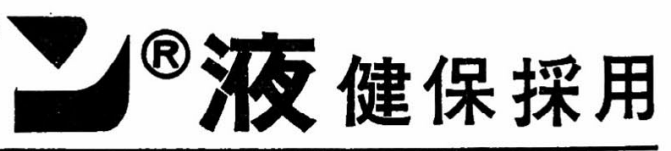

【特

長】

（1）粘液浴解作用がきわめて迅速且つ強力に発現する。

（2）腿性・非腿性の粘性物いつれに対しても分解効力 を発掸する。

（3）気道粘膜をおかさず、無剌激で、汪とんと副作用 を証めない。
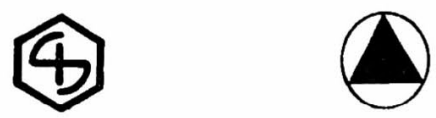

販壳武田薬品工業株式会社 大阪市東区道修町 2 丁目 27 番地

製造千政製薬株式会社 大阪市北区北同心町 1 丁目 83 番地 